RESEARCH ARTICLE

\title{
Identification of Health Knowledge of Lung Function in Predicting Respiratory Disorders in Smokers
}

\author{
Amelia Lorensia, ${ }^{1}$ Rivan Virlando Suryadinata, ${ }^{2}$ Lalita Tirsa ${ }^{1}$ \\ ${ }^{1}$ Department of Clinical-Community Pharmacy, Faculty of Pharmacy, Universitas Surabaya, Surabaya, Indonesia, \\ Salatiga, Indonesia, Nursing Study Program, Faculty of Medicine and Health Sciences, \\ Universitas Kristen Satya Wacana, Salatiga, Indonesia
}

\begin{abstract}
Chronic obstructive pulmonary disease (COPD) is a high risk for active smokers. Early assessment of the condition of lung function is needed to prevent a decrease in lung function. Knowledge of self-management that determines lung health. The purpose of this study was to determine the knowledge of lung function health in predicting respiratory disorders. The study design was a case-control from August 2018 to January 2019. Data was collected through a questionnaire, namely a lung health knowledge questionnaire consisting of categories: risk factors, symptoms, and therapy for respiratory disorders. The research sample was adult men who work in the transportation sector in Surabaya city using purposive sampling. Data analysis using chi-square. The data obtained were 300 people, consisting of 126 people without lung function disorders and 174 people with pulmonary function disorders. The risk factor knowledge category showed a significant difference $(\mathrm{p}=0.000)$ between the group, with the most disorders at the low knowledge level (42.0\%). The symptom knowledge category showed a significant difference $(\mathrm{p}=0.000)$ between groups, and most of the groups with disorders were at a low knowledge level (55.8\%). The category of knowledge of respiratory symptoms showed a significant difference $(\mathrm{p}=0.000)$ between groups, with the knowledge level in both of them mostly at a sufficient level. Therefore, low lung function health knowledge reflects low lung function conditions.
\end{abstract}

Keywords: Knowledge, lung function, smokers

\section{Identifikasi Pengetahuan Kesehatan Fungsi Paru dalam Memprediksi Gangguan Pernapasan pada Perokok}

\begin{abstract}
Abstrak
Penyakit paru obstruktif kronik (PPOK) berisiko tinggi dialami oleh perokok aktif. Pengkajian dini terhadap kondisi fungsi paru diperlukan untuk mencegah penurunan fungsi paru. Pengetahuan tentang manajemen diri yang menentukan kesehatan paru. Tujuan penelitian ini adalah mengetahui pengetahuan kesehatan fungsi paru dalam memprediksi gangguan pernapasan. Desain penelitian adalah case-control dari Agustus 2018 hingga Januari 2019. Pengumpulan data dilakukan melalui kuesioner, yaitu kuesioner pengetahuan kesehatan paru yang terdiri atas kategori: faktor risiko, gejala, dan terapi gangguan pernapasan. Sampel penelitian adalah laki-laki dewasa yang bekerja di sektor transportasi di Kota Surabaya dengan menggunakan purposive sampling. Analisis data menggunakan chi-square. Data yang diperoleh sebanyak 300 orang, terdiri atas 126 orang tanpa gangguan fungsi paru dan 174 orang dengan gangguan fungsi paru. Kategori pengetahuan faktor risiko menunjukkan perbedaan yang bermakna $(\mathrm{p}=0,000)$ antarkelompok dengan gangguan terbanyak pada kelompok tingkat rendah $(42,0 \%)$. Kategori pengetahuan gejala menunjukkan perbedaan yang bermakna $(\mathrm{p}=0,000)$ antarkelompok dan sebagian besar kelompok dengan gangguan berada pada kelompok tingkat rendah $(55,8 \%)$. Kategori pengetahuan gejala pernapasan menunjukkan perbedaan yang bermakna $(\mathrm{p}=0,000)$ antarkelompok dengan tingkat pengetahuan keduanya sebagian besar pada tingkat cukup. Oleh karena itu, pengetahuan kesehatan fungsi paru yang rendah mencerminkan kondisi fungsi paru yang rendah.
\end{abstract}

Kata kunci: Fungsi paru, pengetahuan, perokok

Received: 5 March 2021; Revised: 5 August 2021; Accepted: 5 August 2021; Published: 31 August 2021

Correspondence: Dr. Amelia Lorensia, S.Farm., M.Farm.Klin., Apt. Department of Clinical-Community Pharmacy, Faculty of Pharmacy, Universitas Surabaya. Jln. Raya Kalirungkut, Surabaya 60293, East Java, Indonesia. E-mail: amelia.lorensia@gmail.com 


\section{Introduction}

The lungs are the internal organs most susceptible to infection due to the external environment's influence due to constant exposure to particles, chemicals, and organisms in the air. If the respiratory system's primary function does not work properly, there will be a disturbance in the respiratory system. ${ }^{1}$ Some examples of respiratory disorders are asthma, sleep apnea, chronic obstructive pulmonary disease (COPD), and lung cancer. $^{2}$ Respiratory disease is the leading cause of death and disability in the world. Approximately 65 million people suffer from COPD, and 3 million die each year, making it the third leading cause of death worldwide. ${ }^{3}$ In Indonesia, respiratory problems such as lower respiratory tract infections and chronic respiratory diseases are among the top 10 causes of death and have become an economic burden. ${ }^{4}$ Respiratory disorders can cause disability and death in almost all world regions, which can occur in all groups of society, especially environmental exposure and poverty, increasing vulnerability to this disease. ${ }^{3}$

The risk factor for smoking is one of the most significant causes of COPD.5,6 Cigarette smoke also has a high prevalence as a cause of respiratory symptoms and pulmonary function disorders. ${ }^{7}$ In developing countries, deaths from COPD have also increased due to the increased number of people who consume cigarettes. In China, smoking causes $12 \%$ of mortality and is expected to increase to $30 \%$ by 2030 . COPD mortality is higher in males and will increase in the $>45$ years age group due to decreased respiratory function at $30-40$ years of age. ${ }^{8}$

In this pandemic, chronic lung diseases (such as COPD, asthma, pulmonary fibrosis, and lung cancer) are at high risk of developing severe conditions if infected with COVID-19. Patients with severe and or uncontrolled asthma/COPD are at a higher risk of more severe COVID-19 infection. ${ }^{9,10}$ Smokers who have COPD have a higher risk of developing severe COVID-19 pneumonia than non-smokers. Smoking and vaping are linked to inflammation of the lungs and decreased immune function in the lungs' airways, both of which can increase the likelihood of complications if exposed to COVID-19. Therefore, long-term smokers and e-cigarette users may have a higher risk of developing chronic lung conditions associated with severe cases. ${ }^{11,12}$

Assessment of decreased lung function is necessary to prevent, diagnose, and evaluate various respiratory disorders. ${ }^{13}$ Spirometry is the gold standard for examining lung function and is a simple method to measure how a person inhales or exhales. ${ }^{13}$ Failure to use appropriate diagnostic tools can further contribute to misjudgment. Although spirometry is an essential tool for diagnosing COPD, it is widely underutilized, even if available in medical practice. A survey of 943 primary care found that, although 64\% of practices had access to spirometry, only $34 \%$ used it routinely. ${ }^{14}$ So this study aims to prove whether the common knowledge assessed by the pulmonary function health knowledge questionnaire can help describe respiratory problems in smokers as someone who is at high risk for decreased lung function. It is because not all people at risk of respiratory problems are aware of the terminology of the disease. ${ }^{15}$ Most of them have many misconceptions about respiratory disorders and lack basic knowledge about respiratory disorders. ${ }^{16,17}$ Knowledge is essential in the management of a person's illness, self-management in order to avoid disease, and can affect a person's lifestyle. ${ }^{18,19}$

Self-management includes daily activities in which individuals engage and their families, communities, and health care professionals to manage chronic illnesses. ${ }^{20}$ Individual self-management can profoundly affect their quality of life and health outcomes. Identifying factors affecting self-management can improve self-management assessments. Inform the development of interventions by identifying potential mediators and moderators of behavior or self-management processes, and help individuals with chronic disease engage in sustainable productive and self-managed processes. $^{20}$ Identification of knowledge is also essential as a preventive measure and evaluation of respiratory disorders. ${ }^{17}$ Low level of knowledge is related to inappropriate behavioral attitudes in patients with impaired pulmonary function. So that this less specific behavior can reduce lung function, knowledge of pulmonary function health can delay disease progression, improve self-management strategies, and have a better quality of life. ${ }^{21}$ The purpose of this study was to identify knowledge of lung function health in predicting respiratory problems in smokers.

\section{Methods}

The research design was a case-control study 
that was conducted from August 2018 to January 2019. Ethical clearance for this study was obtained from the Institutional Ethical Committee of the University of Surabaya, with certificate No. 034/KE/I/2018. Data was collected through a questionnaire using paper-based, namely a questionnaire on lung function health knowledge. The blueprint for the preparation of the questionnaire can be seen in Table 1. In this study, the variable measured was the knowledge level of respiratory disorders, including risk factors for respiratory disorders, ${ }^{22-31}$ symptoms of respiratory disorders, ${ }^{22,32-34}$ and treatment/ therapy of respiratory disorders; ${ }^{22,35,36}$ as well as pulmonary function with an $\mathrm{FEV}_{1} / \mathrm{FEC}$ (forced expiration volume in one second/forced vital capacity) assessment.

The population used in the study was male adults. This study involved only the male gender because of differences in stigma and views so that gender can affect knowledge. ${ }^{37}$ In addition, the risk of smoking on respiratory disorders was also influenced by gender. ${ }^{38}$ The sample was adult men aged 18-59 years, active smokers, working in the transportation sector, as a public transport driver, and domiciled in Surabaya city, East Java. The sampling technique was purposive sampling.

The questionnaire on lung function health knowledge consisted of three categories: knowledge of risk factors for respiratory disorders, knowledge of respiratory symptoms, and knowledge of respiratory medicine and therapy. First, the correct statement was given a score of 1 , while the incorrect was given a score of 0 . Then they were assessed and categorized based on the previously calculated cut-off value (Table 2).

The calculations to determine the category of the results of the measurement of knowledge about respiratory symptoms are as follows: ${ }^{39}$ good $(\geq 76 \%)$, enough $(56 \%)$, and less $(<56 \%)$. The data analysis used in this study was a different

Table 1 Blueprint of the Lung Function Health Knowledge Questionnaire

\begin{tabular}{|c|c|c|c|}
\hline Question Category & Topics & Number & References \\
\hline $\begin{array}{l}\text { Knowledge of risk } \\
\text { factors for respiratory } \\
\text { disorders }\end{array}$ & $\begin{array}{l}\text { Environmental pollution risk factors } \\
\text { Risk factors for smoking } \\
\text { Work environment risk factors } \\
\text { Residence risk factors } \\
\text { Age risk factors } \\
\text { Risk factors for disease }\end{array}$ & $\begin{array}{l}1,2 \\
3,4 \\
5,6 \\
7,8 \\
9 \\
10,11\end{array}$ & $\begin{array}{l}22-24 \\
22,25,26 \\
22,27 \\
22,28 \\
22,29 \\
22,30,31\end{array}$ \\
\hline $\begin{array}{l}\text { Knowledge of } \\
\text { respiratory disorders } \\
\text { symptoms }\end{array}$ & $\begin{array}{l}\text { Out of breath } \\
\text { Chronic cough } \\
\text { Wheezing } \\
\text { Respiration problems }\end{array}$ & $\begin{array}{l}1,2 \\
3,4 \\
5 \\
6\end{array}$ & $\begin{array}{l}22,32 \\
22,33 \\
22,34 \\
22\end{array}$ \\
\hline $\begin{array}{l}\text { Knowledge of } \\
\text { treatment and therapy } \\
\text { of respiratory disorders }\end{array}$ & $\begin{array}{l}\text { Medical treatment } \\
\text { Quit smoking } \\
\text { Breathing exercises } \\
\text { Physical activity }\end{array}$ & $\begin{array}{l}1,2,3 \\
4,5 \\
6,7 \\
8\end{array}$ & $\begin{array}{l}22,35 \\
22,35 \\
22 \\
22,36\end{array}$ \\
\hline
\end{tabular}

Table 2 Classification of Health Knowledge of Lung Function Questionnaire Assessment

\begin{tabular}{lcccc}
\hline \multirow{2}{*}{ Category of Knowledge Question } & \multirow{2}{*}{$\begin{array}{c}\text { Number of } \\
\text { Questions }\end{array}$} & \multicolumn{3}{c}{$\begin{array}{c}\text { Number of Correct Answers for } \\
\text { the Knowledge Level Assessment }\end{array}$} \\
\cline { 3 - 5 } & & Good & Enough & Less \\
\hline Risk factors for respiratory disorders & 11 & $9-11$ & $6-8$ & $\leq 5$ \\
Respiratory disorders symptoms & 6 & $5-6$ & $3-4$ & $\leq 2$ \\
$\begin{array}{l}\text { Treatment and therapy of respiratory } \\
\text { disorders }\end{array}$ & 8 & $7-8$ & $5-6$ & $\leq 4$ \\
\hline
\end{tabular}


Table 3 Results of the Validity Test of Knowledge of Risk Factors for Respiratory Disorders

\begin{tabular}{|c|c|c|c|c|}
\hline $\begin{array}{l}\text { Category of } \\
\text { Knowledge } \\
\text { Question }\end{array}$ & No. & Question & $\begin{array}{l}\text { Corrected } \\
\text { Item-Total } \\
\text { Correlation }\end{array}$ & Conclusion \\
\hline \multirow{11}{*}{$\begin{array}{l}\text { Risk factors } \\
\text { for respiratory } \\
\text { disorders }\end{array}$} & 1 & $\begin{array}{l}\text { Highly polluted environments can be at greater } \\
\text { risk of respiratory problems. }\end{array}$ & 0.492 & Valid \\
\hline & 2 & $\begin{array}{l}\text { Combustion fumes can cause respiratory } \\
\text { problems. }\end{array}$ & 0.665 & Valid \\
\hline & 3 & Smoking is not a cause of respiratory problems. & 0.590 & Valid \\
\hline & 4 & $\begin{array}{l}\text { The more cigarettes smoked, the higher the risk } \\
\text { factors for respiratory problems. }\end{array}$ & 0.464 & Valid \\
\hline & 5 & $\begin{array}{l}\text { Working in a dusty environment will not } \\
\text { experience respiratory problems. }\end{array}$ & 0.362 & Valid \\
\hline & 6 & $\begin{array}{l}\text { Working in industrial areas has worse lung } \\
\text { conditions. }\end{array}$ & 0.452 & Valid \\
\hline & 7 & $\begin{array}{l}\text { Living in a city is more at risk of experiencing } \\
\text { respiratory problems than living in a village. }\end{array}$ & 0.664 & Valid \\
\hline & 8 & $\begin{array}{l}\text { Living in industrial areas is more at risk of } \\
\text { experiencing respiratory problems. }\end{array}$ & 0.487 & Valid \\
\hline & 9 & $\begin{array}{l}\text { Increasing age does not increase the risk of } \\
\text { respiratory problems. }\end{array}$ & 0.469 & Valid \\
\hline & 10 & $\begin{array}{l}\text { Some respiratory diseases can be inherited or } \\
\text { passed down from the birth family. }\end{array}$ & 0.431 & Valid \\
\hline & 11 & $\begin{array}{l}\text { A history of respiratory disorders in infants and } \\
\text { children can give disability to adulthood. }\end{array}$ & 0.517 & Valid \\
\hline \multirow{6}{*}{$\begin{array}{l}\text { Respiratory } \\
\text { disorders } \\
\text { symptoms }\end{array}$} & 1 & $\begin{array}{l}\text { Shortness of breath is not a symptom of } \\
\text { respiratory problems. }\end{array}$ & 0.487 & Valid \\
\hline & 2 & $\begin{array}{l}\text { Shortness of breath can get worse during } \\
\text { activities. }\end{array}$ & 0.598 & Valid \\
\hline & 3 & $\begin{array}{l}\text { A cough that doesn't go away is a symptom of a } \\
\text { respiratory disease. }\end{array}$ & 0.433 & Valid \\
\hline & 4 & $\begin{array}{l}\text { Wheezing (such as a whistling sound or a } \\
\text { 'wheezing' sound when breathing in) is a } \\
\text { symptom of respiratory disease. }\end{array}$ & 0.621 & Valid \\
\hline & 5 & $\begin{array}{l}\text { Increased breathing rate is not a sign of } \\
\text { worsening condition. }\end{array}$ & 0.499 & Valid \\
\hline & 6 & $\begin{array}{l}\text { Increased respiratory rate is often found in } \\
\text { patients with respiratory disorders. }\end{array}$ & 0.413 & Valid \\
\hline \multirow{8}{*}{$\begin{array}{l}\text { Treatment } \\
\text { and therapy } \\
\text { of respiratory } \\
\text { disorders }\end{array}$} & 1 & $\begin{array}{l}\text { Cough symptoms can be reduced with } \\
\text { medication (medicine) given. }\end{array}$ & 0.364 & Valid \\
\hline & 2 & $\begin{array}{l}\text { Medications (drugs) are given only to reduce } \\
\text { symptoms. }\end{array}$ & 0.408 & Valid \\
\hline & 3 & Treatment (medicine) given can cure. & 0.390 & Valid \\
\hline & 4 & Quitting smoking does not reduce symptoms. & 0.556 & Valid \\
\hline & 5 & Quitting smoking makes breathing better. & 0.366 & Valid \\
\hline & 6 & Breathing exercises to increase breathing effort. & 0.544 & Valid \\
\hline & 7 & $\begin{array}{l}\text { Breathing muscle exercises cannot reduce the } \\
\text { symptoms of shortness of breath. }\end{array}$ & 0.683 & Valid \\
\hline & 8 & $\begin{array}{l}\text { Body activity program (sports) to increase } \\
\text { tolerance for physical activity. }\end{array}$ & 0.362 & Valid \\
\hline
\end{tabular}


test of the two groups with the chi-square test to determine the differences between the groups with and without pulmonary function disorders.

\section{Results}

The subject was 30 people residing in Surabaya city. Validity and reliability tests were carried out using SPSS for Windows version 24. The validity test results of the knowledge of the risk factors for respiratory disorders showed that all questions from the three categories were valid. The questionnaire is valid if $\mathrm{r}$ count $>$ table $(\mathrm{r}$ tabel $=0.361$ ), and Table 3 shows that the table value for 30 respondents has a value above the table value. The reliability test results were

Table 4 Knowledge Reliability Test Results of Risk Factors for Respiratory Disorders

\begin{tabular}{lcc}
\hline \multirow{2}{*}{ Category of Knowledge } & \multicolumn{2}{c}{ Reliability Statistic } \\
\cline { 2 - 3 } & $\begin{array}{c}\text { Cronbach's } \\
\text { Alpha }\end{array}$ & N of Item \\
\hline Risk factors for respiratory disorders & 0.719 & 11 \\
Respiratory disorders symptoms & 0.604 & 6 \\
Treatment and therapy of respiratory disorders & 0.672 & 8 \\
\hline
\end{tabular}

Table 5 Frequency Distribution of Respondent Characteristics

\begin{tabular}{|c|c|c|c|c|}
\hline \multirow{3}{*}{ Respondent Characteristics } & \multicolumn{4}{|c|}{ Division of Groups based on Lung Function } \\
\hline & \multicolumn{2}{|c|}{$\begin{array}{l}\text { No Impaired Lung } \\
\text { Function }(n=126)\end{array}$} & \multicolumn{2}{|c|}{$\begin{array}{c}\text { Impaired Lung Function } \\
(\mathrm{n}=174)\end{array}$} \\
\hline & Frequency & $\%$ & Frequency & $\%$ \\
\hline \multicolumn{5}{|l|}{ Age (years) } \\
\hline Late adolescence (15-25) & o & 0.0 & 2 & 1.1 \\
\hline Early adulthood (26-35) & 5 & 4.0 & 9 & 5.2 \\
\hline Late adulthood (36-45) & 58 & 46.0 & 19 & 10.9 \\
\hline Early elderly $(46-55)$ & 43 & 34.1 & 52 & 29.9 \\
\hline Late elderly $(56-65)$ & 20 & 15.8 & 25 & 14.4 \\
\hline \multicolumn{5}{|l|}{ Level of education } \\
\hline No school & 15 & 11.9 & 35 & 20.1 \\
\hline Kindergarten & o & 0.0 & 2 & 1.2 \\
\hline Elementary school & 58 & 46.0 & 104 & 59.8 \\
\hline Junior high school & 19 & 15.1 & 19 & 10.9 \\
\hline Senior high school & 34 & 27.0 & 14 & 8.1 \\
\hline \multicolumn{5}{|l|}{$\operatorname{BMI}\left(\mathrm{kg} / \mathrm{m}^{2}\right)^{40}$} \\
\hline Thin & 15 & 11.9 & 11 & 6.3 \\
\hline Normal & 87 & 69.0 & 127 & 73.0 \\
\hline Overweight & 19 & 15.1 & 22 & 12.7 \\
\hline Obesity & 5 & 4.0 & 11 & 6.3 \\
\hline \multicolumn{5}{|l|}{ History of disease } \\
\hline Diabetes & o & 0.0 & 4 & 2.3 \\
\hline Hyperuricemia & o & 0.0 & 3 & 1.7 \\
\hline Hypertension & o & 0.0 & 4 & 2.3 \\
\hline Dyslipidemia & o & 0.0 & 3 & 1.7 \\
\hline Don't know/don't exist & 126 & 100.0 & 159 & 91.4 \\
\hline \multicolumn{5}{|l|}{ Lung fungtion value $\left(\mathrm{FEV}^{1} / \mathrm{FVC}\right)(\%)^{22}$} \\
\hline No decrease $(\geq 80)$ & 126 & 100.0 & 0 & 0.0 \\
\hline Decrease mild level $\left(65^{-<80)}\right.$ & o & 0.0 & 76 & 43.7 \\
\hline Decrease moderate level $(50-<65)$ & o & 0.0 & 94 & 54.0 \\
\hline Decrease severe level $(<50)$ & o & 0.0 & 4 & 2.3 \\
\hline
\end{tabular}


declared reliable because they had Cronbach alpha values between 0.61-0.80 (Table 4).

The data obtained in the study were 300 people consisting of 126 people who did not experience lung function problems and 174 people who had lung function disorders. Based on the frequency of respondent characteristics, the age category in the respondent's group without pulmonary function disorders was mostly in late adulthood 36-45 years (46.0\%), and those with pulmonary function disorders were most in early elderly $46-$ 55 years (29.9\%). In the education level category, elementary school education level was the highest in the two groups. In the body mass index (BMI) category ${ }^{40}$ respondents had normal BMI in both groups (Table 5).

Table 6 shows categories of the knowledge level of lung function health. The knowledge level of lung function health in the knowledge category of risk factors for respiratory disorders showed a significant difference $(\mathrm{p}=\mathrm{o} .000)$ between the groups without pulmonary function disorders and lung function disorders. Most of the groups with impaired lung function were at the low knowledge level (42.0\%). Whereas without any disruption in lung function, most of them were at a sufficient knowledge level (50.0\%). In the category of knowledge of respiratory symptoms, there was a significant difference $(p=0.000)$ between the groups without pulmonary function disorders and those with pulmonary function disorders. Most of the groups with impaired lung function were at a low knowledge level (55.8\%). Whereas without any disruption in lung function, most of them were at a sufficient knowledge level (50.0\%). In the category of knowledge of respiratory symptoms, there was a significant difference $(\mathrm{p}=0.000)$ between the groups without pulmonary function disorders and those with lung function disorders, with the knowledge level in the two groups most at the sufficient knowledge level.

\section{Discussion}

This study involved respondents with active smokers because many young people smoke, and the prevalence of smokers is increasing from year to year. Indonesia is also the third-largest cigarette consumer in the world. ${ }^{41}$ Previous studies related to respiratory diseases and smoking had discussed the effect of smoking on the health of lung function, ${ }^{42-44}$ related to the economy, ${ }^{45}$ or smoking cessation..$^{46}$ In Indonesia, similar studies on the knowledge level of lung function health in smokers, such as the level of danger of smoking, ${ }^{47}$ impact oral health, ${ }^{48}$ are generally carried out at young ages and students. However, similar research on public transport drivers does not yet exist, and what exists is a picture of food intake, such as rickshaw drivers. ${ }^{49}$

The risk factor for smoking is one of the most significant influential causes of COPD..$^{\circ}$ Cigarette smoke also has a high prevalence as a cause of respiratory symptoms and pulmonary function disorders..$^{51}$ Assessment of decreased lung function uses a lung function test, an objective measurement of whether a person's lung function is normal or abnormal. Pulmonary function tests are usually performed based on specific indications or needs. Pulmonary function tests were carried out by assessing the function

Table 6 Categories of the Knowledge Level of Lung Function Health

\begin{tabular}{|c|c|c|c|c|c|c|}
\hline \multirow{3}{*}{ Category } & \multirow{3}{*}{$\begin{array}{c}\text { Knowledge } \\
\text { Level }\end{array}$} & \multicolumn{4}{|c|}{ Division of Groups based on Lung Function } & \multirow{3}{*}{ p Value } \\
\hline & & \multicolumn{2}{|c|}{$\begin{array}{l}\text { No Impaired Lung } \\
\text { Function }(n=126)\end{array}$} & \multicolumn{2}{|c|}{$\begin{array}{c}\text { Impaired Lung } \\
\text { Function }(n=174)\end{array}$} & \\
\hline & & Frequency & $\%$ & Frequency & $\%$ & \\
\hline $\begin{array}{l}\text { Risk factors for } \\
\text { respiratory disorders }\end{array}$ & $\begin{array}{l}\text { Good } \\
\text { Enough } \\
\text { Less }\end{array}$ & $\begin{array}{l}20 \\
63 \\
43\end{array}$ & $\begin{array}{l}15.9 \\
50.0 \\
34.1\end{array}$ & $\begin{array}{l}38 \\
63 \\
73\end{array}$ & $\begin{array}{l}21.8 \\
36.2 \\
42.0\end{array}$ & 0.000 \\
\hline $\begin{array}{l}\text { Respiratory disorders } \\
\text { symptoms }\end{array}$ & $\begin{array}{l}\text { Good } \\
\text { Enough } \\
\text { Less }\end{array}$ & $\begin{array}{l}39 \\
63 \\
24\end{array}$ & $\begin{array}{l}31.0 \\
50.0 \\
19.0\end{array}$ & $\begin{array}{l}13 \\
64 \\
97\end{array}$ & $\begin{array}{c}7.5 \\
36.8 \\
55.7\end{array}$ & 0.000 \\
\hline $\begin{array}{l}\text { Treatment and } \\
\text { therapy of respiratory } \\
\text { disorders }\end{array}$ & $\begin{array}{l}\text { Good } \\
\text { Enough } \\
\text { Less }\end{array}$ & $\begin{array}{l}39 \\
63 \\
24\end{array}$ & $\begin{array}{l}31.0 \\
50.0 \\
19.0\end{array}$ & $\begin{array}{l}13 \\
64 \\
97\end{array}$ & $\begin{array}{c}7.5 \\
36.8 \\
55 \cdot 7\end{array}$ & 0.000 \\
\hline
\end{tabular}

Note: ${ }^{\text {chi-square test }}$ 
of ventilation, gas diffusion, pulmonary blood perfusion, and transport of $\mathrm{O}_{2}$ and $\mathrm{CO}_{2}$ gases in the blood. ${ }^{21}$ Usually, assessing a person's lung function is sufficient to perform the $\mathrm{FEV}_{1}$ pulmonary ventilation function test. Ventilatory function with good value can represent the overall lung function, and usually, other lung functions are also good. Assessment of ventilation function is closely related to the assessment of respiratory mechanics. A spirometer is used to assess the function of ventilation and record a graph of breathing based on the amount and velocity of air that is exited or entered into the spirometer. ${ }^{21}$ In the study, pulmonary function tests were performed using a hand-held spirometer-type spirometry device. Spirometry was chosen because spirometry is the gold standard for examining lung function and is a simple method that can measure how a person inhales or exhales. ${ }^{22}$

Factors affecting lung function apart from knowledge include age, sex, height, weight, sex, and race..$^{2}$ Changes in the structure of the lungs are mainly associated with an increase in the size of the alveolar space without inflammation or damage to the alveolar wall, which is called senile emphysema. This microscopic emphysema increases linearly with increasing age in nonsmokers, but in smokers, a more progressive increase in alveolar space size can only be observed in specific (susceptible) individuals. Senile emphysema can be a consequence of the loss of the supporting structures of the lung parenchyma. Moreover, it has been observed that the elasticity of the lungs decreases with age. It has been postulated that this phenomenon is due more to the reduced surface tension force of the alveoli due to an increase in the size of the individual diameter compared to changes in elastin and collagen in the pulmonary parenchyma. ${ }^{53}$

Body mass index is often defined as body weight (kilograms) divided by height (meters) squared $\left(\mathrm{kg} / \mathrm{m}^{2}\right)$. BMI is related to body fat, which can categorize obesity and malnutrition in both adults and children. BMI is also used to assess nutritional deficiency, where a $\mathrm{BMI}<18.5 \mathrm{~kg} /$ $\mathrm{m}^{2}$ indicates nutritional deficiency. Malnutrition in COPD is associated with complications and increased mortality. COPD patients with low body weight have a lower diffusion capacity and exercise than normal-weight COPD patients. Reduced body cell mass is associated with reduced diaphragm mass and respiratory muscle mass. Malnutrition is also associated with decreased immune status, so that unwanted complications can occur, such as nosocomial lung infections and hypercapnic lung failure. 54

A limitation in this study was that this study does not assess the severity of smoking which can affect respiratory symptoms and pulmonary function disorders. ${ }^{7}$ Examination of lung function uses a type of hand-held spirometers, a type of spirometry that was easy and affordable. However, they differ in values from more accurate spirometry types such as bellows spirometer or rolling seal.

\section{Conclusions}

The knowledge level of lung function health, there were differences in the knowledge category of risk factors for respiratory disorders, symptoms of respiratory disorders, and treatment and therapy of respiratory disorders between groups without lung function disorders and with impaired lung function. Suggestions for future research are to increase the assessment of risk factors that can affect lung function. In addition, it is necessary to carry out similar research on respondents with different characters, such as different occupations that are at risk of exposure to respiratory problems (construction workers, mining workers, parking attendants), or differences in education, gender, and e-cigarette smokers.

\section{Conflict of Interest}

All authors stated that there was no conflict of interest in this study.

\section{Acknowledgments}

Researchers would like to thank the Institute of Research and Community Service of the Universitas Surabaya.

\section{References}

1. Lo Mauro A, Aliverti A. Physiology of respiratory disturbances in muscular dystrophies. Breathe(Sheff). 2016;12(4):31827.

2. Damianaki A, Vagiakis E, Sigala I, Pataka A, Rovina N, Vlachou A, et al. The coexistence of obstructive sleep apnea and 
bronchial asthma: revelation of a new asthma phenotype? J Clin Med. 2019;8(9):1476.

3. Quaderi SA, Hurst JR. The unmet global burden of COPD. Glob Health Epidemiol Genom. 2018;3:e4.

4. Kementerian Perencanaan Pembangunan Nasional/Badan Perencanaan Pembangunan Nasional. Kajian sektor kesehatan: transisi demografi dan epidemiologi: permintaan pelayanan kesehatan di Indonesia [Internet]. Jakarta: Kementerian Perencanaan Pembangunan Nasional/Badan Perencanaan Pembangunan Nasional; 2019 [cited 2021 January 20]. Available from: https://www. bappenas.go.id/files/8515/9339/1872/FA_ Preview_HSR_Booko1.pdf.

5. Muro S. Cigarette smoking is the most important causal factor for developing chronic obstructive pulmonary disease (COPD). Nihon Rinsho. 2011;69(10):173540.

6. Lee SJ, Kim SW, Kong KA, Ryu YJ, Lee JH, Chang JH. Risk factors for chronic obstructive pulmonary disease among never-smokers in Korea. Int $\mathrm{J}$ Chron Obstruct Pulmon Dis. 2015;10:497-506.

7. Bird Y, Staines-Orozco H. Pulmonary effects of active smoking and secondhand smoke exposure among adolescent students in Juárez, Mexico. Int J Chron Obstruct Pulmon Dis. 2016;11:1459-67.

8. Oemiati R. Kajian epidemiologis penyakit paru obtruktif kronis (PPOK). Media Penelit Pengemb Kes. 2013;23(2):82-8.

9. Daccord C, Touilloux B, Von Garnier C. Asthma and COPD management during the COVID-19 pandemic. Rev Med Suisse. 2020;16(692):933-8.

10. Sin DD. COVID-19 in COPD: a growing concern. EClinicalMedicine. 2020;26:100546.

11. Kaur G, Lungarella G, Rahman I. SARSCoV-2 COVID-19 susceptibility and lung inflammatory storm by smoking and vaping. J Inflamm. 2020;17:21.

12. McAlinden KD, Eapen MS, Lu W, Chia C, Haug G, Sohal SS. COVID-19 and vaping: risk for increased susceptibility to SARS-CoV-2 infection? Eur Respir J. 2020;56(1):2001645.

13. Sim YS, Lee JH, Lee WY, Suh DI, Oh YM, Yoon JS, et al. Spirometry and bronchodilator test. Tuberc Respir Dis (Seoul). 2017;80(2):10512.
14. Fromer L. Diagnosing and treating COPD: understanding the challenges and finding solutions. Int J Gen Med. 2011;4:729-39.

15. Walker SL, Saltman DL, Colucci R, Martin L, Canadian Lung Association Advisory Committee. Awareness of risk factors among persons at risk for lung cancer, chronic obstructive pulmonary disease and sleep apnea: a Canadian population-based study. Can Respir J. 2010;17(6):287-94.

16. Booth S, Johnson MJ. Improving the quality of life of people with advanced respiratory disease and severe breathlessness. Breathe (Sheff). 2019;15(3):198-215.

17. Gupta A, Ravaliya V, Mishra D, Dani V, Sodawala C, Shah H, et al. Assessment of knowledge, attitude, and behavior about the disease process and physiotherapy management in patients with chronic obstructive pulmonary disease: a qualitative study. J Educ Health Promot. 2019;8:15.

18. Grady PA, Gough LL. Self-management: a comprehensive approach to management of chronic conditions. Am J Public Health. 2014;104(8):e25-31.

19. Schulman-Green D, Jaser S, Martin F, Alonzo A, Grey M, McCorkle R, et al. Processes of self-management in chronic illness. J Nurs Scholarsh. 2012;44(2):136-44.

20. Schulman-Green D, Jaser SS, Park C, Whittemore R. A metasynthesis of factors affecting self-management of chronic illness. J Adv Nurs. 2016;72(7):1469-89.

21. Ranu H, Wilde M, Madden B. Pulmonary function tests. Ulster Med J. 2011;80(2):8490.

22. Global Initiative for Chronic Obstructive Lung Disease (GOLD). Global strategy for the diagnosis, management, and prevention of chronic obstructive pulmonary disease: 2020 report [Internet]. GOLD online; 2020 [cited 2021 January 20]. Available from: https:// goldcopd.org/wp-content/uploads/2019/12/ GOLD-2020-FINAL-ver1.2-03Dec19_WMV. pdf.

23. Kim D, Chen Z, Zhou LF, Huang SX. Air pollutants and early origins of respiratory diseases. Chronic Dis Transl Med. 2018;4(2):75-94.

24. Shankar A, Dubey A, Saini D, Singh M, Prasad CP, Roy S, et al. Environmental and occupational determinants of lung cancer. Transl Lung Cancer Res. 2019;8(Suppl 
1): $\mathrm{S} 31-49$.

25. Trofor AC, Papadakis S, Lotrean LM, RaduLoghin C, Eremia M, Mihaltan F, et al. Knowledge of the health risks of smoking and impact of cigarette warning labels among tobacco users in six European countries: findings from the EUREST-PLUS ITC Europe surveys. Tob Induc Dis. 2018;16(Suppl 2):A10.

26. Dawood OT, Rashan MA, Hassali MA, Saleem F. Knowledge and perception about health risks of cigarette smoking among Iraqi smokers. J Pharm Bioallied Sci. 2016;8(2):146-51.

27. Dalju I, Dessie A, Bogale L, Mekonnen TH. Occupational risk factors associated with respiratory symptoms among tannery workers in Mojo town, Southeast Ethiopia, 2018: a comparative cross-sectional study. Multidiscip Respir Med. 2019;14:27.

28. Van Gageldonk-Lafeber AB, van der Sande MA, Heijnen ML, Peeters MF, Bartelds AI, Wilbrink B. Risk factors for acute respiratory tract infections in general practitioner patients in the Netherlands: a case-control study. BMC Infect Dis. 2007;7:35.

29. MacNee W, Rabinovich RA, Choudhury G. Ageing and the border between health and disease. Eur Res J. 2014;44(5):1332-52.

30. Putcha N, Drummond MB, Wise RA, Hansel NN. Comorbidities and chronic obstructive pulmonary disease: prevalence, influence on outcomes, and management. Semin Respir Crit Care Med. 2015;36(4):575-91.

31. Ishii M, Yamaguchi Y, Hamaya H, Ogawa S, Imura M, Akishita M. Characteristics of factors for decreased lung function in elderly patients with type 2 diabetes. Sci Rep. 2019;9(1):20206.

32. Berliner D, Schneider N, Welte T, Bauersachs $J$. The differential diagnosis of dyspnea. Dtsch Arztebl Int. 2016;113(49):834-45.

33. Amos LB. Cough. In: Kliegman RM, Lye PS, Bordini BJ, Toth H, Basel D, editors. Nelson pediatric symptom-based diagnosis. $1^{\text {st }}$ Edition. Philadelphia; Elsevier; 2018. p. $15-38$.

34. Marcus BS, McAvay G, Gill TM, Vaz Fragoso CA. Respiratory symptoms, spirometric respiratory impairment, and respiratory disease in middle-aged and older persons. $\mathbf{J}$ Am Geriatr Soc. 2015;63(2):251-7.

35. Lorensia A, Yudiarso A, Arrahmah R.
Evaluasi pengetahuan dan persepsi obat batuk swamedikasi oleh perokok. MKMI. 2018;4(4):395-405.

36. Lorensia A, Suryadinata RV, Chandra NLMR. Profil status vitamin D, aktivitas fisik dan kesehatan paru pada tukang bangunan. CoMPHI J. 2020;1(2):117-24.

37. Lorensia A, Yudiarso A, Pratama AM. Intrepretative phenomenological analysis: perception of health risk of smoking and smoking cessation among pharmacy students. Anima. 2016;31(4):170-9.

38. Nicolini A, Barbagelata E, Tagliabue E, Colombo D, Monacelli F, Braido F. Gender differences in chronic obstructive pulmonary diseases: a narrative review. Panminerva Med. 2018;60(4):192-9.

39. Arikunto S. Prosedur penelitian: suatu pendekatan praktik. Jakarta: Rineka Cipta; 2013.

40. Nuttall FQ. Body mass index: obesity, BMI, and health: a critical review. Nutr Today. 2015;50(3):117-28.

41. World Health Organization. Global adult tobacco survey: Indonesia report 2011. New Delhi: World Health Organization Regional Office for South-East Asia; 2012.

42. Jayes L, Haslam PL, Gratziou CG, Powell P, Britton J, Vardavas C, et al., Tobacco Control Committee of the European Respiratory Society. SmokeHaz: systematic reviews and meta-analyses of the effects of smoking on respiratory health. Chest. 2016;150(1):16479.

43. Gogou E, Kotsiou OS, Siachpazidou DS, Pinaka M, Varsamas C, Bardaka F, et al. Underestimation of respiratory symptoms by smokers: a thorn in chronic obstructive pulmonary disease diagnosis. NPJ Prim Care Respir Med. 2021;31(1):14.

44. West R. Tobacco smoking: health impact, prevalence, correlates and interventions. Psychol Health. 2017;32(8):1018-36.

45. Jha P. The hazards of smoking and the benefits of cessation: a critical summation of the epidemiological evidence in high-income countries. eLife. 2020;9:e49979.

46. Tashkin DP. Smoking cessation in chronic obstructive pulmonary disease. Semin Respir Crit Care Med. 2015;36(4):491-507.

47. Rompis K, Wowor VNS, Pangemanan DHC. Tingkat pengetahuan bahaya merokok bagi kesehatan gigi mulut pada siswa SMK Negeri 
8 Manado. e-Clinic. 2019;7(2):98-102.

48. Aziizah KN, Setiawan I, Lelyana S. Hubungan tingkat pengetahuan tentang dampak rokok terhadap kesehatan rongga mulut dengan tingkat motivasi berhenti merokok pada mahasiswa Universitas Kristen Maranatha. SONDE. 2018;3(1):16-21.

49. Lorensia A, Suryadinata RV, Sidabutar BCM. Effect analysis of protein intake of pedicab driver in Surabaya. J Trop Pharm Chem. 2021;5(3):188-93.

50. Singh D, Agusti A, Anzueto A, Barnes PJ, Bourbeau J, Celli BR, et al. Global strategy for the diagnosis, management, and prevention of chronic obstructive lung disease: the GOLD science committee report 2019. Eur Respir J. 2019;53(5):1900164.

51. Vanker A, Gie RP, Zar HJ. The association between environmental tobacco smoke exposure and childhood respiratory disease: a review. Expert Rev Respir Med. 2017;11(8):661-73.

52. Talaminos Barroso A, Márquez Martín E, Roa Romero LM, Ortega Ruiz F. Factors affecting lung function: a review of the literature. Arch Bronconeumol (Engl Ed). 2018;54(6):32732.

53. Brandsma CA, de Vries M, Costa R, Woldhuis RR, Königshoff M, Timens W. Lung ageing and COPD: is there a role for ageing in abnormal tissue repair? Eur Resp Rev. 2017;26(146):170073.

54. Landbo C, Prescott E, Lange P, Vestbo J, Almdal TP. Prognostic value of nutritional status in chronic obstructive pulmonary disease. Am J Respir Crit Care Med. 1999;160(6):1856-61. 